\title{
Petrology of a margarite-bearing meta-anorthosite from Sel- jeneset, Nordfjord, western Norway: Implications for the $P-T$ history of the Western Gneiss Region during Caledonian uplift
}

\author{
SPENCER J. COTKIN ${ }^{\prime *}$, JOHN W. VALLEY' and ERIC J. ESSENE? \\ 'Department of Geology and (reophysics, University of Wisconsin, 1215 West Davton Street, Madison, WI53706 (L.S.4.) \\ 'Department of Geological Sciences, University of Michigan, Ann Arbor. MI 48109 (L.S.A.)
}

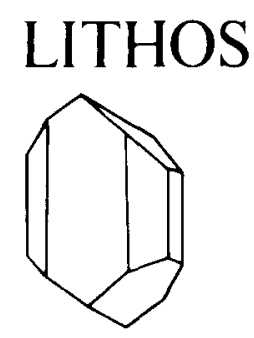

Cotkin, S.J., Valley, J.W. and Essene, E.J., 1988. Petrology of a margarite-bearing meta-anorthosite from
Seljeneset, Nordfjord, western Norway: Implications for the $P$-T history of the Western Gneiss Region
during Caledonian uplift. Lithos, 21: $117-128$.

\begin{abstract}
The Western Gneiss Region of Norway contains relics of eclogite and high-pressure granulite that have been extensively overprinted by amphibolite-facies assemblages. A meta-anorthosite from Seljeneset, Nordfjord, contains fine-grained margarite +quartz+plagioclase \pm muscovite clots set in a zoisite + quartz + plagioclase \pm clinozoisite matrix. In some clots relict kyanite is preserved. Equilibria modeled in the CASH system indicate a retrograde $P-T$ path that begins in the kyanite + zoisite field $(P>8.2 \mathrm{kbar})$, passes through reaction (1), kyanite + zoisite + quartz $\rightleftharpoons$ anorthite $+\mathrm{H}_{2} \mathrm{O}$, between $610^{\circ} \mathrm{C}$ and about $800^{\circ} \mathrm{C}$. and finally through reaction (2), kyanite + anorthite $+\mathrm{H}_{2} \mathrm{O} \rightleftharpoons$ margarite + quartz. The sodic composition of plagioclase in reaction (1) suggests that pressures in excess of $15-17 \mathrm{kbar}\left(\right.$ at $750-800^{\circ} \mathrm{C}$ ) may have been experienced during Silurian eclogite-facies metamorphism. The simplified CASH reaction (2) occurs between invariant points at $4.3 \mathrm{kbar}, 520^{\circ} \mathrm{C}$ and $8.2 \mathrm{kbar} .610^{\circ} \mathrm{C}$, but polyvariance, due to variable $\mathrm{Na}$ solid solution, broadens the reaction into a band about $150^{\circ} \mathrm{C}$ wide. Cooling through $500^{\circ} \mathrm{C}$ occurred about $410 \mathrm{Ma}$ ago. This study provides the first well-defined $P-T$ path for Caledonian retrograde metamorphism at amphibolite-facies conditions.
\end{abstract}

(Received September 25. 1986; revised and accepted July 15, 1987)

\section{Introduction and geologic setting}

The Western Gneiss Region (WGR) of Norway is a classic area for the study of high-grade metamorphic rocks (e.g., Eskola, 1921). Relics of garnet-bearing lithologies, including eclogite, garnet peridotite and granulite, occur locally and have received considerable attention (e.g., Bryhni et al., 1977; Krogh, 1977; Lappin and Smith, 1978; Medaris, 1984; Griffin et al., 1985). Most of the WGR, however, has been extensively overprinted by amphibolite-facies assemblages (Lappin, 1966). Although numerous estimates of metamorphic pressures and temperatures have been determined for high-grade assemblages, relatively few estimates

\footnotetext{
*Present address: Division of Geological and Planetary Sciences. California Institute of Technology, Pasadena. CA 91125 . U.S.A.
}

are available for amphibolite-facies assemblages (Griffin et al., 1985). The margarite-bearing metaanorthosite from Seljeneset, outer Nordfjord, western Norway, the subject of this paper, is one rock type that has allowed an accurate estimate of amphibolite-facies pressures and temperatures.

The Nordfjord area (Fig. 1) is underlain predominantly by quartzo-feldspathic gneiss, with lesser amounts of eclogite, peridotite, anorthosite and mangerite (Bryhni, 1966). The region was subjected to eclogite-facies metamorphism during the Silurian Caledonian orogeny, when the Baltic plate was overridden by the Greenland plate (Krogh, 1977; Griffin and Brueckner, 1980; Cuthbert et al., 1983). In part, evidence for the Silurian age for the high-grade metamorphic event comes from $\mathrm{Sm}-\mathrm{Nd}$ dates from garnet-clinopyroxene pairs from eclogites of about $425 \mathrm{Ma}$ (Griffin and Brueckner, 


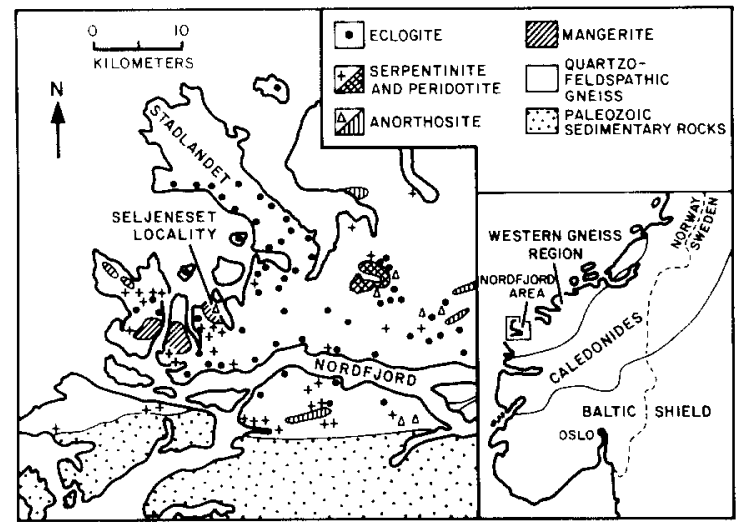

Fig. 1. Generalized geologic map of the Nordfjord area. Simplified after Bryhni (1966)

1980). The age of retrograde metamorphism has been studied by Lux (1985) in the vicinity of Seljeneset and also to the north in the Stadlandet area (Fig. 1) by $\mathrm{K}-\mathrm{Ar}$ and ${ }^{40} \mathrm{Ar} /{ }^{39} \mathrm{Ar}$ techniques. He concluded that cooling through $500^{\circ} \mathrm{C}$ (approximately the temperature of concern in this study) occurred about $410 \mathrm{Ma}$ ago, shortly after eclogite formation. A Svecofennian age of $1760 \pm 70 \mathrm{Ma}$ was derived for the protolith of the quartzo-feldspathic gneiss in the Stadlandet area by $\mathrm{Rb}-\mathrm{Sr}$ (whole rock; Lappin e1 al., 1979). Lappin et al. (1979) also obtained a $\mathrm{U}-\mathrm{Pb}$ age on zircon of $1520 \pm 10 \mathrm{Ma}$ from mangerite spatially related to the meta-anorthosite, which they interpreted as a crystallization age of the mangerite. The intrusion age of the anorthosite is unknown.

Rocks of the Seljeneset locality were first described by Eskola (1921). Meta-anorthosite consists of pink ellipsoidal margarite-bearing clots set in a white well-foliated zoisite-rich matrix. The long dimension of the clots defines a lineation. Eskola noted lenses and boudins of eclogite intricately associated with meta-anorthosite and assumed a primary relationship between the two lithologies.

In 1981 the senior author collected a sample of the margarite-bearing meta-anorthosite and in 1984 obtained four additional samples from Professor W.L. Griffin of Oslo. During subsequent examination. kyanite was identified within several of the clots, and it became apparent that useful pressuretemperature $(P-T)$ information could be derived from a detailed study. In this paper we report the results of a petrographic and microprobe study of the available samples.

\section{Petrography}

Margarite-bearing clots are fine-grained, $1-5 \mathrm{~cm}$ in diameter, and contain subequal amounts of margarite, quartz, plagioclase and muscovite. These phases are invariably less than $100 \mu \mathrm{m}$ in diameter, and are commonly much finer-grained. Fibrous to platy, randomly oriented phyllosilicates are generally $2-10 \mu \mathrm{m}$ in thickness. Quartz and plagioclase are granoblastic. Several of the clots contain large skeletal grains of kyanite (Fig. 2a), equal in dimension to entire clots. Within each clot kyanite grains are optically continuous and show sharp uniform extinction under crossed nicols, indicating that kyanite is not strained. The following assemblages have been defined on the basis of touching grains. In clots the predominant assemblages are margarite + quartz + plagioclase \pm muscovite (Fig. 2b) and margarite + quartz + kyanite \pm muscovite (Fig. 2c). Kyanite and plagioclase were rarely observed coexisting and are generally separated by a thin selvage of margarite (Fig. 2d). In a few places, however, the assemblage margarite + quartz + kyanite + plagioclase \pm muscovite was observed (Fig. 2e). Even less common is the assemblage kyanite + plagioclase + quartz. These textures lead to the important conclusion that kyanite has reacted with plagioclase to produce margarite.

In contrast with the complicated textures in the clots, the matrix displays relatively simple textures. suggesting a close approach to equilibrium during retrogradation. Layering in the matrix, defined by differing proportions of constituent phases. imparts a strong planar fabric to the rocks. Strongly aligned, euhedral to subhedral zoisite, $0.1-0.5 \mathrm{~mm}$ in length, is the most abundant phase in the matrix, generally constituting $50-95 \%$ by mode (Fig. 2a). Lesser amounts of quartz, plagioclase. and commonly clinozoisite are also present. The modal ratio zoisite/(zoisite + clinozoisite) varies from 0.9 to 1.0 . Minor to trace brown biotite. green hornblende. muscovite, chlorite, rutile (rimmed by sphene), or apatite also occur locally in the matrix, but are generally restricted to thin layers. With the exception of the sphene rims on rutile all textures are consistent with a single final re-equilibration in the matrix, presumably during the amphibolite-facies portion of uplift. The most common assemblage in the matrix is zoisite + quartz + plagioclase \pm clinozoisite. Other assemblages in the matrix are 

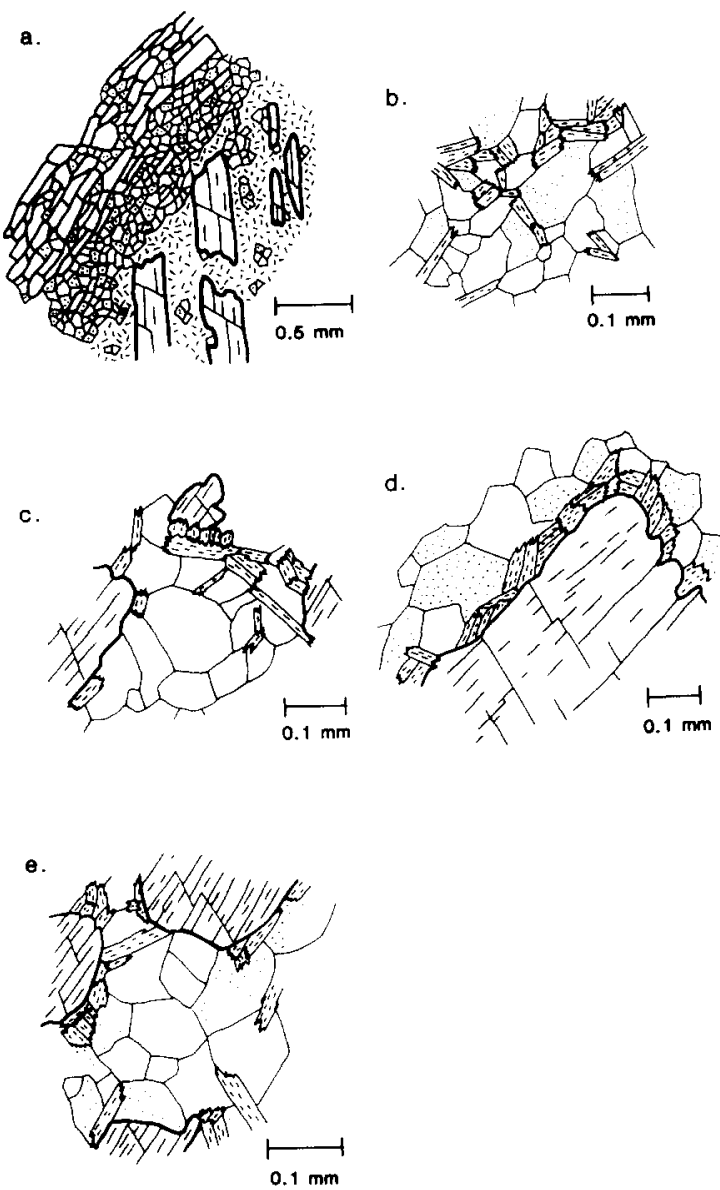

Fig. 2. Sketches of typical textures in margarite-bearing metaanorthosite

a. Relationship between clots (lower right) and matrix (upper left), separated by a quartz-plagioclase reaction rim. Highrelief minerals are zoisite (no cleavage) and kyanite (with cleavage). Low-relief polygonal grains are plagioclase (stippled) and quartz (no pattern). Randomly oriented dashes represent fine-grained margarite. Within clots, islands of relict optically-continuous kyanite reside in a margarite + quartz + plagioclase matrix. The reaction rim suggests that kyanite and zoisite reacted to form plagioclase [i.e. reaction (1)]. Sample 328.

b. Assemblage margarite + quartz + plagioclase in a clot from sample 328 .

c. Assemblage margarite + quartz + kyanite in a clot fromsample N-5-3.

d. Margarite selvages separating kyanite and plagioclase in a clot from sample $\mathrm{N}-5-3$. This texture indicates that reaction (2) occurred in a retrograde direction.

e. Assemblage margarite +quartz + plagioclase + kyanite in a clot from sample $\mathrm{N}-5-3$.

Note: the grain size of margarite has been exaggerated for clarity. quartz + plagioclase \pm hornblende \pm biotite \pm muscovite and quartz + plagioclase + sphene.

A zone, $0.5-1.0 \mathrm{~mm}$ in width, consisting primarily of quartz and plagioclase. generally occurs between clots and matrix (Fig. 2a). These zones also contain minor and variable amounts of muscovite, biotite, amphibole and chlorite. Rutile rimmed by ilmenite was observed in one place.

\section{Mineral chemistry}

\section{Analytical techniques}

Constituent minerals were analyzed by a ninechannel ARL-SEMQ electron microprobe at the University of Wisconsin. An operating voltage of 15 $\mathrm{kV}$, a sample current of about $15 \mathrm{nA}$, and a counting time of $30 \mathrm{~s}$ were used for zoisite, clinozoisite, margarite, plagioclase and amphibole. For muscovite and biotite a sample current of $10 \mathrm{nA}$ and a $5 \mathrm{~s}$ counting time was employed. A beam spot of approximately $2 \mu \mathrm{m}$ was used for all phases. Well-analyzed natural silicates were used as standards. Corrections were made by the methods of Bence and Albee (1968) using the $\alpha$-factors of Albee and Ray (1970). Analyses of zoisite and clinozoisite represent averages of three points. Many of the analyses of margarite, plagioclase and amphibole are singlepoint analyses due to the extremely fine-grained size of these phases. For muscovite and biotite two to seven points were averaged for each analysis and are thus considered semi-quantitative.

Representative grains of margarite, muscovite, amphibole, zoisite and clinozoisite from sample $\mathrm{N}$ 5-3 were analyzed for fluorine. For all grains $F$ was below detectable limits of $0.03 \mathrm{wt} . \%$.

Iron is reported as total Fe, except for zoisite and clinozoisite, where $\mathrm{Fe}$ is assumed to be $\mathrm{Fe}^{3+}$, and for amphibole, where $\mathrm{Fe}^{2+} / \mathrm{Fe}^{3+}$ was calculated from charge-balance considerations.

\section{Margarite}

Margarite displays a wide degree of solid solution toward paragonite (Table 1), with $\mathrm{Ca} /(\mathrm{Ca}+\mathrm{Na}$ ) ranging from 0.64 to 0.84 (Fig. 3 ). Minor solid solution toward muscovite is present, with $\mathrm{K}_{2} \mathrm{O}$ varying from below detectable limits to $0.57 \mathrm{wt} . \%$. Minor 
Representative analyses of margarite, muscovite and biotite

\begin{tabular}{|c|c|c|c|c|c|c|c|}
\hline \multirow{3}{*}{$\begin{array}{l}\text { Sample } \\
\text { Grann }\end{array}$} & \multicolumn{4}{|c|}{ Margarite } & \multicolumn{2}{|c|}{ Muscovite } & \multirow{3}{*}{$\begin{array}{l}\text { Biotite } \\
328 \\
3 \mathrm{H}\end{array}$} \\
\hline & \multirow{2}{*}{$\begin{array}{l}328 \\
1 A A\end{array}$} & \multicolumn{3}{|c|}{ WLG-IA } & \multirow{2}{*}{$\begin{array}{l}328 \\
3 J^{\prime \prime \prime}\end{array}$} & \multirow{2}{*}{$\begin{array}{l}N-5-3 \\
3 C^{2}\end{array}$} & \\
\hline & & $2 \mathrm{E}$ & $3 \mathrm{D}$ & $2 \mathrm{C}$ & & & \\
\hline Silo & 33.06 & 32.03 & 33.11 & 30.61 & 45.73 & 45.46 & 35.34 \\
\hline 110$)$ & 49.58 & 50.51 & 51.02 & 51.39 & 32.80 & 34.59 & 19.85 \\
\hline$\Gamma i 0$ & b.d. & n.a. & na. & n.a. & 0.54 & 0.40 & 2.06 \\
\hline $\mathrm{Fe}^{(1)}$ & 1.08 & 1.03 & 0.76 & 0.82 & 2.53 & 2.35 & 12.73 \\
\hline $\mathrm{Mg}()$ & 0.19 & 0.44 & 0.26 & 0.38 & 2.18 & 1.46 & 14.37 \\
\hline $\mathrm{MnO}$ & b.d. & n.a. & n.a. & n.a. & b.d. & b.d. & b.d. \\
\hline $\mathrm{CaC}$ & 9.06 & 9.43 & 9.85 & 11.60 & b.d. & b.d. & b.d. \\
\hline Na.d) & 2.61 & 2.38 & 1.68 & 1.22 & 0.14 & 0.79 & 0.07 \\
\hline $\mathrm{K},(1)$ & 0.10 & b.d. & 0.30 & b.d. & 12.22 & 10.94 & 10.87 \\
\hline [otial & $\overline{95.68}$ & $\overline{95.82}$ & $\overline{96.98}$ & $\overline{96.02}$ & $\overline{96.14}$ & $\overline{95.99}$ & $\overline{95.29}$ \\
\hline $\mathrm{Si}$ & 2.173 & 2.105 & 2.145 & 2.017 & 3.076 & 3.039 & 2.628 \\
\hline $81^{12}$ & 1.827 & 1.895 & 1.855 & 1.983 & 0.924 & 0.961 & 1.372 \\
\hline+111 & 2.014 & 2.029 & 2.040 & 2.008 & 1.676 & 1.764 & 0.367 \\
\hline $\mathrm{Ti}$ & - & - & - & - & 0.027 & 0.020 & 0.115 \\
\hline $\mathrm{Fe}$ & 0.060 & 0.057 & 0.041 & 0.045 & 0.142 & 0.131 & 0.791 \\
\hline $\mathrm{Mg}$ & 0.018 & 0.043 & 0.025 & 0.037 & 0.219 & 0.145 & 1.593 \\
\hline $\mathrm{Mn}$ & - & - & - & - & - & - & - \\
\hline $\mathrm{Ca}$ & 0.638 & 0.664 & 0.684 & 0.819 & - & - & - \\
\hline $\mathrm{Na}$ & 0.333 & 0.303 & 0.211 & 0.153 & 0.018 & 0.102 & 0.010 \\
\hline K & 0.008 & - & 0.025 & - & 1.049 & 0.932 & 1.031 \\
\hline 1 & 0.652 & 0.687 & 0.743 & 0.843 & - & - & - \\
\hline $1 \cdots$ & 0.340 & 0.313 & 0.229 & 0.157 & 0.017 & 0.099 & 0.010 \\
\hline$I_{h}$ & 0.008 & - & 0.027 & - & 0.983 & 0.901 & 0.990 \\
\hline
\end{tabular}

b.d. $=$ helow detection limit. $n . a .=$ not analyzed: $m=$ matrix: $c=c l o t$. Micas arbitrarily normalized to 11 oxygens on an anhydrous basis.

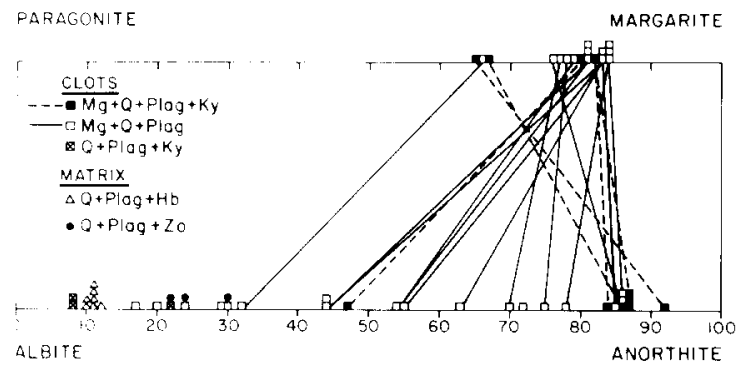

Fig. 3. Plagioclase and margarite compositions. Tie-lines connect coexisting grains. $\mathrm{Mg}=$ margarite: $\mathrm{Q}=$ quartz; $\mathrm{K}_{y}=$ kyanite: $\mathrm{Hb}=$ hornblende: $\mathrm{Zo}=$ zoisite.

amounts of $\mathrm{FeO}$ and $\mathrm{MgO}$ are also present (0.74-1.18 and $0.19-0.62 \mathrm{wt} \%$, respectively).

\section{Muscovite}

Muscovite does not deviate greatly from its ideal formula, although grains from clots and matrix can be distinguished (Table 1). Muscovite from clots contains 3.00 to $3.20 \mathrm{Si}$ per formula unit and has 6-12 mole\% paragonite component. Muscovite from the matrix contains 3.06 to $3.21 \mathrm{Si}$ per formula unit and has 1-3 mole $\%$ paragonite component. No solid solution toward margarite was detected.

\section{Biotite}

Biotite is peraluminous (Table 1 ), containing $1.26-1.46 \mathrm{Al}^{\mathrm{V} V}$ per formula unit. The $\mathrm{Fe} /(\mathrm{Fe}+\mathrm{Mg})$ ranges from 0.33 to 0.36 , close to the $\mathrm{Fe} /(\mathrm{Fe}+\mathrm{Mg})=0.333$ that is commonly used to separate biotite from phlogopite.

\section{Plagioclase}

Plagioclase from clots displays a wide spectrum of compositions (Table 2; Fig. 3). Plagioclase coexisting with quartz+ margarite is $\mathrm{An}_{17-86}$, that co- 
TABLE ?

Representative analyses of plagioclase

\begin{tabular}{|c|c|c|c|c|c|c|c|c|}
\hline \multirow{3}{*}{$\begin{array}{l}\text { Sample } \\
\text { Cirain }\end{array}$} & \multicolumn{5}{|l|}{ Clots } & \multirow{2}{*}{\multicolumn{3}{|c|}{$\frac{\text { Matrix }}{N-5-3}$}} \\
\hline & \multicolumn{2}{|l|}{ WLG-1A } & \multicolumn{3}{|l|}{328} & & & \\
\hline & ID & $1 \mathrm{H}$ & $1 \mathrm{~A}$ & $3 \mathrm{HH}$ & lB & $3 G$ & $1 \mathrm{D}$ & $4 D$ \\
\hline $\mathrm{SiO}_{2}$ & 50.13 & 53.73 & 60.70 & 46.29 & 67.26 & 65.22 & 58.80 & 62.60 \\
\hline $\mathrm{Al}_{2} \mathrm{O}_{3}$ & 32.51 & 29.17 & 24.26 & 34.72 & 20.13 & 22.15 & 26.76 & 23.99 \\
\hline $\mathrm{FeO}$ & 0.13 & 0.14 & 0.13 & 0.15 & 0.11 & 0.23 & 0.14 & 0.15 \\
\hline $\mathrm{MgO}$ & b.d. & b.d. & b.d. & b.d. & b.d. & b.d. & b.d. & b.d. \\
\hline $\mathrm{CaO}$ & 14.07 & 11.07 & 6.49 & 17.56 & 1.83 & 2.44 & 7.63 & 4.54 \\
\hline $\mathrm{Na}, \mathrm{O}$ & 3.41 & 5.27 & 8.37 & 1.49 & 10.93 & 10.38 & 7.23 & 8.86 \\
\hline $\mathrm{K}, \mathrm{O}$ & b.d. & b.d. & b.d. & b.d. & b.d. & b.d. & b.d. & b.d. \\
\hline Total & $\overline{100.25}$ & $\overline{99.38}$ & $\overline{99.95}$ & $\overline{100.21}$ & $\overline{100.26}$ & $\overline{100.42}$ & 700.56 & $\overline{100.14}$ \\
\hline $\mathrm{Si}$ & 2.276 & 2.440 & 2.706 & 2.124 & 2.944 & 2.859 & 2.610 & 2.763 \\
\hline Al & 1.739 & 1.562 & 1.274 & 1.878 & 1.038 & 1.144 & 1.400 & 1.248 \\
\hline $\mathrm{Fc}$ & 0.005 & 0.005 & 0.005 & 0.006 & 0.004 & 0.008 & 0.005 & 0.006 \\
\hline $\mathrm{Mg}$ & - & - & - & - & - & - & - & - \\
\hline $\mathrm{Ca}$ & 0.684 & 0.539 & 0.310 & 0.863 & 0.086 & 0.114 & 0.360 & 0.215 \\
\hline $\mathrm{Na}$ & 0.300 & 0.464 & 0.723 & 0.133 & 0.928 & 0.882 & 0.622 & 0.758 \\
\hline $\mathrm{k}$ & - & - & - & - & - & - & - & - \\
\hline$A n$ & 70 & 55 & 30 & 87 & 8 & 12 & 37 & 22 \\
\hline $\begin{array}{c}\text { Coexisting } \\
\text { phases }\end{array}$ & $\mathrm{Q}+\mathrm{M}$ & $Q+M$ & $Q+M$ & $\mathrm{Q}+\mathrm{M}+\mathrm{K}$ & $Q+K$ & $Q+H$ & $Q+Z+S$ & $Q+Z$ \\
\hline
\end{tabular}

$\mathrm{Q}=$ quartz: $\mathrm{M}=$ margarite $\mathrm{K}=$ kyanite; $\mathrm{H}=$ hornblende, $\mathrm{Z}$ = zoisite: $\mathrm{S}=$ sphene; b.d. = below detection limit. Formulae normalized 108 oxygens

existing with quartz + margarite + kyanite is mostly $\mathrm{An}_{84-92}$, and that coexisting with kyanite + quartz is sodic $\left(\mathrm{An}_{8-22}\right)$. In the matrix, plagioclase coexisting with zoisite + quartz is $\mathrm{An}_{22-30}$, whereas that coexisting with hornblende + quartz is $\mathrm{An}_{10-12}$.

\section{Zoisite and clinozoisite}

Fourteen pairs of coexisting zoisite and clinozoisite are shown in Fig. 4 and representative analyses are given in Table 3. Zoisite varies from $\mathrm{Ps}_{4.2-4.8}$ (with one grain of $\mathrm{Ps}_{6.4}$ ) and clinozoisite from $\mathrm{PS}_{13.2-16.9}$

\section{Amphibole}

Eleven very fine-grained amphiboles from a 1.0 $\mathrm{mm}$ thick layer, composed of amphibole, plagioclase $\left(\mathrm{An}_{10-12}\right)$ and quartz, were analyzed. All amphiboles are calcic and have similar $\mathrm{Mg} /(\mathrm{Mg}+\mathrm{Fe})$ of 0.63-0.76. However, based on the Si content and $(\mathrm{Na}+\mathrm{K})$ in the $A$ site, two populations of amphibole were defined. The first group contains 6.2-6.4 Si and $0.54-0.69(\mathrm{Na}+\mathrm{K}){ }_{4}$ per formula unit. These

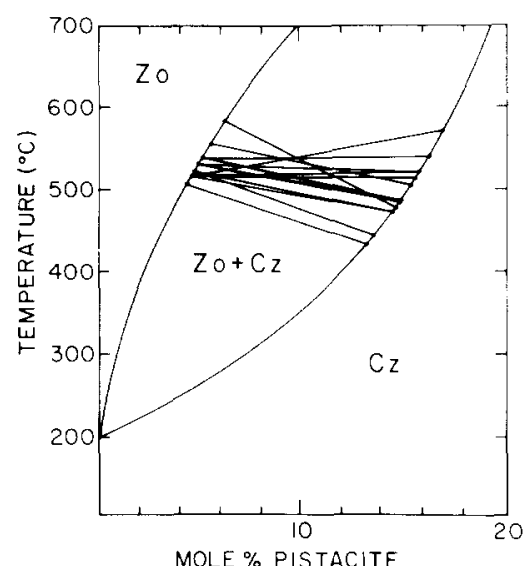

Fig. 4. Composition of coexisting zoisite and clinozoisite. The two-phase zoisite $(\mathrm{Zo})+$ clinozoisite $(\mathrm{Cz})$ field is from Prunier and Hewitt (1985). Pistacite $=\mathrm{Fe}^{3+} /\left(\mathrm{Fe}^{3+}+\mathrm{Al}\right)$.

are pargasitic hornblende, ferroan pargasitic hornblende, and ferroan pargasite, according to the classification of Leake (1978). The second group contains 6.7-7.0 Si and 0.32-0.46 $(\mathrm{Na}+\mathrm{K})_{A}$ per formula unit, and are magnesio-hornblende accord- 
TABLE 3

Representative analyses of coexisting zoisite-clinozoisite pairs

\begin{tabular}{|c|c|c|c|c|c|c|}
\hline \multirow{2}{*}{$\begin{array}{l}\text { Sample } \\
\text { Grain }\end{array}$} & \multicolumn{2}{|l|}{328} & \multicolumn{2}{|l|}{328} & \multicolumn{2}{|l|}{$N-5-3$} \\
\hline & $3 \mathrm{~B}$ & $3 A$ & $6 \mathrm{~F}$ & $6 \mathrm{E}$ & $4 A$ & $4 C$ \\
\hline $\operatorname{siO}$ & 39.07 & 38.30 & 38.83 & 38.24 & 38.48 & 37.00 \\
\hline $\mathrm{Al}, \mathrm{O}$ & 30.64 & 25.91 & 30.53 & 26.74 & 32.60 & 28.49 \\
\hline $\mathrm{Fe}, \mathrm{O}_{3}$ & 2.27 & 7.69 & 2.22 & 7.11 & 2.29 & 6.94 \\
\hline $\mathrm{CaO}$ & 25.04 & 24.89 & 24.88 & 24.65 & 24.56 & 24.43 \\
\hline Total & $\overline{97.02}$ & $\overline{96.77}$ & $\overline{96.46}$ & $\overline{96.74}$ & $\overline{97.93}$ & $\overline{96.86}$ \\
\hline $\mathrm{Si}$ & 3.036 & 3.090 & 3.034 & 3.072 & 2.956 & 2.968 \\
\hline 11 & 2.806 & 2.464 & 2.811 & 2.531 & 2.952 & 2.694 \\
\hline $\mathrm{Fe}^{3}$ & 0.132 & 0.466 & 0.130 & 0.430 & 0.132 & 0.418 \\
\hline Ca & 2.084 & 2.152 & 2.082 & 2.121 & 2.022 & 2.100 \\
\hline Mole $\%$ Ps & 4.5 & 15.9 & 4.4 & 14.5 & 4.4 & 13.6 \\
\hline
\end{tabular}

Ti. Mg. Mn, Na and K were analyzed but were not detected at the 0.05 wt. $\%$ level. Formulae normalized to 12.5 oxygens.

ing to Leake (1978). Representative analyses are given in Table 4.

TABLE 4

Representative analyses of hornblende

\begin{tabular}{|c|c|c|}
\hline \multirow{2}{*}{$\begin{array}{l}\text { Sample } \\
\text { Grain }\end{array}$} & \multicolumn{2}{|l|}{$N-5-3$} \\
\hline & $3 F_{2}$ & $3 \mathrm{Fl}$ \\
\hline $\mathrm{SiO}$ & 42.94 & 47.31 \\
\hline $\mathrm{Al}, \mathrm{O}_{3}$ & 12.57 & 7.62 \\
\hline $\mathrm{TiO}$ & 0.64 & 0.79 \\
\hline $\mathrm{FeO}$ & 15.30 & 12.35 \\
\hline $\mathrm{MgO}$ & 11.09 & 14.09 \\
\hline $\mathrm{MnO}$ & b.d. & b.d. \\
\hline $\mathrm{CaO}$ & 12.00 & 12.39 \\
\hline $\mathrm{Na}, \mathrm{O}$ & 1.53 & 0.87 \\
\hline $\mathrm{K}-\mathrm{O}$ & 1.14 & 0.59 \\
\hline Total & 97.21 & 96.01 \\
\hline $\mathrm{Si}$ & 6.376 & 6.972 \\
\hline$A l^{11}$ & 1.624 & 1.028 \\
\hline$\left.A\right|^{13}$ & 0.575 & 0.295 \\
\hline $\mathrm{Ti}$ & 0.070 & 0.086 \\
\hline $\mathrm{Fe}^{i:}$ & 0.432 & 0.292 \\
\hline $\mathrm{Fe}^{\prime \prime}$ & 1.468 & 1.231 \\
\hline $\mathrm{Mg}$ & 2.455 & 3.095 \\
\hline $\mathrm{Mn}$ & - & - \\
\hline $\mathrm{Ca}$ & 1.910 & 1.956 \\
\hline $\mathrm{Na}^{1 / 4}$ & 0.090 & 0.044 \\
\hline $\mathrm{Na}^{\prime}$ & 0.350 & 0.204 \\
\hline K & 0.217 & 0.111 \\
\hline
\end{tabular}

b. d. =below detection limits. Formulae calculated by summing $\mathrm{Si}+$ $\mathrm{Al}+\mathrm{Ti}+\mathrm{Fe}+\mathrm{Mg} 1013$ and $\mathrm{Fe}^{3+}$ was calculated to maintain charge balance.

\section{Petrogenesis}

\section{Interpretation of textures}

The textures described above suggest that in the early part of the Caledonian history of these rocks, porphyroblasts of kyanite resided in a zoisite + (minor) quartz matrix. Reaction between kyanite and zoisite produced the plagioclase +quartz rims that surround clots. Subsequently, kyanite and plagioclase reacted in the clots to form margarite. The margarite clots are therefore interpreted as pseudomorphs after porphyroblastic kyanite.

The well-developed foliation and lineation were evidently produced during the early part of the Caledonian history, probably during eclogite-facies metamorphism. The event that produced the clots apparently was not accompanied by significant deformation, as evidenced by strain-free kyanite.

\section{Evaluation of equilibria in the system $\mathrm{CASH}$}

Phase equilibria of the meta-anorthosite may be modeled in the system $\mathrm{CaO}-\mathrm{Al}_{2} \mathrm{O}_{3}-\mathrm{SiO}_{2}-\mathrm{H}_{2} \mathrm{O}$ (CASH). A portion of the petrogenetic grid of Perkins et al. (1980) is shown in Fig. 5. Chatterjee et al. (1984) have also published a petrogenetic grid for the CASH system. However, the placement by Chatterjee et al. of invariant points (IP's) I and II, which are important in the present study, is not consistent with the experimental determinations of 


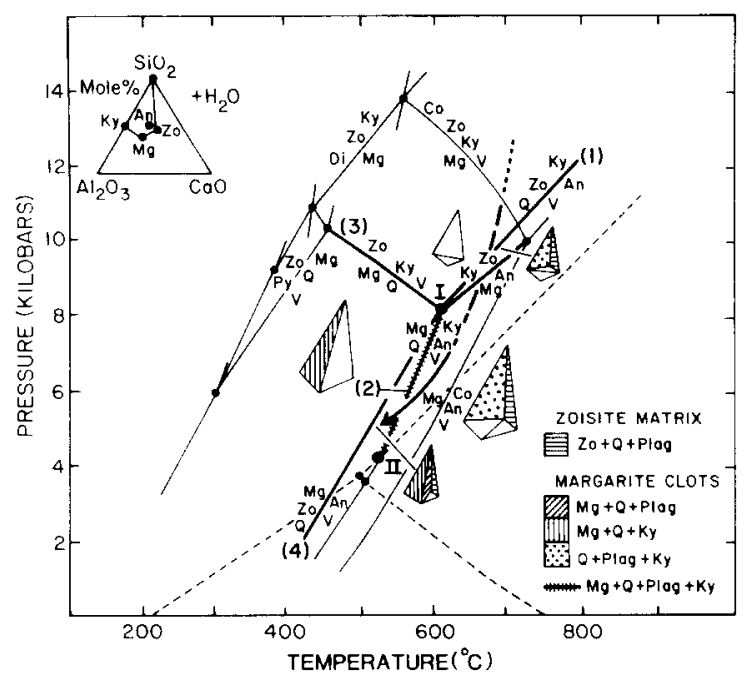

Fig. 5. Petrogenetic grid for a portion of the CASH system. after Perkins et al. (1980). Observed assemblages are indicated in the lower right. The arrow represents the proposed $P-T$ path, and is drawn as a dotted, dashed and solid curve as there is increasing certainty of its placement with decreasing $P$ and $T$. The light dashed lines are the aluminum silicate phase diagram of Holdaway (1971). An=anorthite: $\mathrm{Co}=$ corundum; $\mathrm{Di}=$ diaspore: $\mathrm{Ky}=$ kyanite: $\mathrm{Mg}=$ margarite: $\mathrm{Py}=$ pyrophyllite: $\mathrm{Q}=$ quartz; $\mathrm{V}=$ vapor $=\mathrm{H}_{2} \mathrm{O} ; \mathrm{Zo}=$ zoisite. $\mathrm{I}, \mathrm{II}=$ invariant points discussed in text.

the reactions that emanate from the IP's (see below).

Invariant point I is well constrained at $8.2 \mathrm{kbar}$. $610^{\circ} \mathrm{C}$ by the experimentally reversed reactions:

$$
\begin{aligned}
& \text { kyanite }+2 \text { zoisite }+ \text { quartz } \rightleftharpoons \\
& 4 \text { anorthite }+\mathrm{H}_{2} \mathrm{O} \\
& \text { margarite }+ \text { quartz } \rightleftharpoons \\
& \text { kyanite }+ \text { anorthite }+\mathrm{H}_{2} \mathrm{O} \\
& 4 \text { margarite }+3 \text { quartz } \rightleftharpoons \\
& 5 \text { kyanite }+2 \text { zoisite }+3 \mathrm{H}_{2} \mathrm{O}
\end{aligned}
$$

Reaction (1) was reversed by Goldsmith (1981), reaction (2) by Nitsch et al. (1981) and reaction (3) by Jenkins (1985). Invariant point II is also well constrained by the intersection of reaction (2) and kyanite $\rightleftharpoons$ sillimanite (Newton, 1966). Invariant point II occurs at $4.3 \mathrm{kbar}, 520^{\circ} \mathrm{C}$.

If kyanite and zoisite were once stable together. pressures in excess of $8.2 \mathrm{kbar}$ are indicated (considering only equilibria in the CASH system and without temperature information). The presence of plagioclase in the reaction rims between clots and matrix is consistent with a retrograde $P-T$ path passing through reaction (1) between IP I and about $800^{\circ} \mathrm{C}$ (approximately the highest metamorphic temperature reported from the Nordfjord area; Griffin et al.. 1985).

The observed assemblages and their stability fields (Fig. 5) indicate conditions of final equilibrium in the stability field of kyanite, between reaction (2) and the reaction:

margarite +2 zoisite + quartz $\rightleftharpoons$

$$
5 \text { anorthite }+2 \mathrm{H}_{2} \mathrm{O}
$$

The limiting four-phase assemblage, margarite + quartz + kyanite + plagioclase, is stable along reaction ( 2 ). The margarite selvages between kyanite and plagioclase strongly suggest a retrograde $P$ $T$ path that passes through reaction (2), between IP's I and II, above the kyanite $\rightleftharpoons$ sillimanite transformation. Because margarite does not coexist with zoisite there is no evidence that the $P-T$ path pierced reaction (4), presumably because $\mathrm{Na}$ solid solution in plagioclase has shifted reaction (4) to lower temperature (see discussion on margarite-plagioclase equilibria).

\section{Equilibria outside the CASH system}

Constraints on fluid composition. In the above equilibria, and in the calculations that follow, it has been assumed that $P_{\text {total }}=P_{\mathrm{H}_{2} O}$, i.e. $X_{(\mathrm{O})}$, is negligible. The reaction:

$$
\begin{aligned}
& 2 \text { zoisite }+\mathrm{CO}_{2} \rightleftharpoons \\
& \quad 3 \text { anorthite }+ \text { calcite }+\mathrm{H}_{2} \mathrm{O}
\end{aligned}
$$

restricts the assemblage zoisite + plagioclase to $\mathrm{H}_{2} \mathrm{O}$ rich conditions. The location in $T-X_{\mathrm{H}_{2} \mathrm{O}}$ space of reaction $(5)$ is a function of mineral composition and pressure. The effects of solid solution in zoisite and plagioclase on reaction (5) may be evaluated by assuming that the activity of calcite is equal to unity. The equilibrium expression for solid phases is:

$K_{(5)}=\frac{\left(\alpha_{\mathrm{An}_{n}}\right)^{3}}{\left(\alpha_{Z_{0}}\right)^{2}}=\frac{\left(X_{\mathrm{An}}\right)^{3}\left(\gamma_{\mathrm{An}}\right)^{3}}{\left(X_{Z_{0}}\right)^{2}\left(\gamma_{Z_{0}}\right)^{2}}$

where $\alpha=$ activity; $X=$ mole fraction; and $\gamma=$ activity coefficient. For zoisite, the assumption $\alpha=X$ is made and $\mathrm{Fe}^{3+}$ is considered to reside in the $M 3$ 
site only [cf. data for Fe-poor clinozoisite from Dollase (1971)], giving $X_{\mathrm{zo}_{\mathrm{o}}}=0.925$ and $X_{A 1}^{M 3}=0.775$. (See next section for rationale for $X_{\mathrm{Zo}}=0.925$.) For plagioclase, activity coefficients from Orville (1972) were used. For $X_{\mathrm{An}}=0.25$, $\gamma_{A n}=1.276$. The position of reaction (5) has been calculated for various combinations of $X_{\mathrm{H}_{2}()}$ and $T$ at $6 \mathrm{kbar}$ by the program EQUILI (Wall and Essene, 1972; Valley and Essene, 1980), modified to account for non-ideal mixing of fluid species (W.M. Lamb, pers. commun., 1986) by the methods of Kerrick and Jacobs (1981). These calculations show that for $T>500^{\circ} \mathrm{C}, X_{(())}$, was less than 0.01 . Thus, the approximation that $P_{\text {fluid }}=P_{\mathrm{H}_{2} \mathrm{O}}$ is reasonable.

Zoisite-plagioclase equilibria. Reaction (1) occurs at 8-12 kbar in the CASH system. By considering the effects of additional components on reaction (1), a more meaningful approximation of the pressure at which kyanite and zoisite were last in equilibrium may be made. This can be done if the composition of plagioclase and zoisite, in equilibrium with kyanite, quartz and $\mathrm{H}_{2} \mathrm{O}$ is known. As no direct information on early mineral composition is available several assumptions need to be made. First, because plagioclase is the only Na-bearing phase in most of the matrix, it is assumed that plagioclase, in equilibrium with zoisite + quartz \pm clinozoisite, has retained its original composition [i.e. the composition that was produced by reaction (1)]. Plagioclase in the matrix varies from $\mathrm{An}_{22}$ to $\mathrm{An}_{30}$. $\mathrm{An}$ intermediate value of $\mathrm{An}_{25}$ was used in the calculation below. Second, for a modal ratio of zoisite/(zoisite + clinozoisite) of 0.8 or greater (a condition that is met in all of the samples studied), only one epidote-group mineral occurs at temperature greater than about $600^{\circ} \mathrm{C}$ (see Fig. 4). A zoisite composition of $\mathrm{Ps}_{7.5}$ (i.e. $X_{\mathrm{Zo}}=0.925$ ) is used in the following calculation.

Assuming that the activities of kyanite, quartz and $\mathrm{H}_{2} \mathrm{O}$ are equal to unity, the equilibrium expression for solid phases in reaction ( 1 ) is:

$K_{(1)}=\frac{\left(\alpha_{A_{n}}\right)^{4}}{\left(\alpha_{Z_{0}}\right)^{2}}=\frac{\left(X_{\text {An }}\right)^{4}\left(\gamma_{A n}\right)^{4}}{\left(X_{Z_{.0}}\right)^{2}\left(\gamma_{Z_{0}}\right)^{2}}$

For each value of $K_{(1)}$ the reaction is shifted to lower $T / P$ (if $K_{(1)}<1.0$ ) or higher $T / P\left(K_{(1)}>1.0\right)$. The magnitude of this shift has been calculated from thermochemical data using the program EQUILI and the relation:

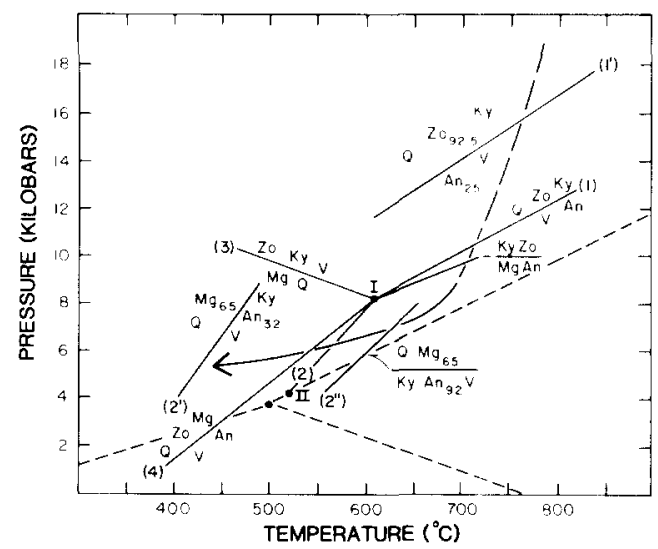

Fig. 6. Positions of reactions (1) and (2) calculated to show the effects of solid solution appropriate for samples of this study.

$\Delta T \Delta S=R T \ln K$

For a value of $K_{11}=0.017$ the corresponding shift in the equilibrium position of reaction ( 1 ) is approximately $+4 \mathrm{kbar}$ or $-175^{\circ} \mathrm{C}$. As peak metamorphic temperatures for the Seljeneset area were approximately $750-800^{\circ} \mathrm{C}$ (Griffin et al., 1985), pressures of 15-17 kbar are indicated (Fig. 6). These pressure estimates are consistent with many reported for the WGR (Griffin et al., 1985).

Margarite-plagioclase equilibria. The partitioning of $\mathrm{Ca} / \mathrm{Na}$ between margarite and plagioclase (i.e. $K_{\mathrm{D}}$ ) is shown in Fig. 3 and Table 5. The crossing tie lines indicate that equilibrium has not been attained or that it has been variably reset on the scale of a thin section. The diagram may also be complicated by low-temperature solvi for plagioclase and by margarite solid solutions. The tie-lines may be separated into three groups: In the first group plagioclase is more calcic than margarite (i.e. $K_{\mathrm{D}}<1.0$ ), in the second group $K_{\mathrm{D}}$ is approximately equal to unity, and in the third group plagioclase is more sodic than margarite $\left(K_{\mathrm{D}}>1.0\right)$. There is a general correlation between $K_{\mathrm{P}}$ and mineral assemblage. With one exception, margarite and plagioclase from the fourphase assemblage, margarite + quartz + kyanite + plagioclase, have a $K_{\mathrm{D}}$ that varies from $<1.0$ to near unity, whereas $K_{\mathrm{D}}$ from the three-phase assemblage, margarite + quart $z+$ plagioclase, varies from near unity to $>1.0$.

To evaluate the effect of additional components, notably $\mathrm{Na}_{2} \mathrm{O}$, on reaction (2) the activity of quartz, 
TABLE 5

Data for margarite-plagioclase equilibrium

\begin{tabular}{|c|c|c|c|c|c|c|c|}
\hline \multirow[t]{2}{*}{ No. } & \multirow[t]{2}{*}{ Sample } & \multicolumn{3}{|c|}{ Plagioclase } & \multicolumn{2}{|c|}{ Margarite } & \multirow[t]{2}{*}{$K_{(2)}$} \\
\hline & & grain & $x_{11}$ & $\gamma_{11}{ }^{(*)}$ & grain & $X_{\text {M1g }}$ & \\
\hline 1 & WLGIA & ID & 0.70 & 1.112 & IE & 0.77 & 1.01 \\
\hline 2 & & $1 G$ & 0.75 & 1.109 & $1 F$ & 0.78 & 1.07 \\
\hline 3 & & $1 \mathrm{H}$ & 0.54 & 1.251 & [II & 0.79 & 0.86 \\
\hline 4 & & $1 \mathrm{H}$ & 0.54 & 1.251 & 112 & 0.81 & 0.83 \\
\hline 5 & & $1 \mathrm{H}$ & 0.54 & 1.251 & 113 & 0.81 & 0.83 \\
\hline 6 & & $1 \mathrm{~J}$ & 0.44 & 1.276 & 112 & 0.81 & 0.69 \\
\hline 7 & & IN & 0.55 & 1.245 & $1 \mathrm{M}$ & 0.83 & 0.82 \\
\hline 8 & & $1 \mathrm{~K}$ & 0.63 & 1.183 & $1 \mathrm{M}$ & 0.83 & 0.90 \\
\hline 4 & & $1 \mathrm{~L}$ & 0.44 & 1.276 & $1 \mathrm{M}$ & 0.83 & 0.68 \\
\hline 10 & & $2 \mathrm{~B}$ & 0.86 & 1.017 & $2 C$ & 0.84 & 1.04 \\
\hline 11 & & $3 A$ & 0.85 & 1.021 & $3 C$ & 0.84 & 1.03 \\
\hline 12 & & $3 B$ & 0.86 & 1.017 & $3 \mathrm{D}$ & 0.74 & 1.18 \\
\hline 13 & & $3 \mathrm{E}$ & 0.78 & 1.056 & $3 G$ & 0.84 & 0.98 \\
\hline 14 & 328 & $1 B B$ & 0.32 & 1.276 & IAA & 0.65 & 0.63 \\
\hline 15 & & $1 \mathrm{EE}$ & 0.92 & 1.000 & IDD & 0.65 & 1.41 \\
\hline 16 & & $2 \mathrm{~A}$ & 0.47 & 1.276 & $2 \mathrm{EE}$ & 0.80 & 0.75 \\
\hline 17 & & $3 \mathrm{CC}$ & 0.84 & 1.025 & $3 \mathrm{BB}$ & 0.82 & 1.05 \\
\hline 18 & & 3DD & 0.87 & 1.013 & $3 \mathrm{BB}$ & 0.82 & 1.07 \\
\hline 19 & & $4 \mathrm{CC}$ & 0.86 & 1.017 & $4 \mathrm{AA}$ & 0.62 & 1.41 \\
\hline
\end{tabular}

Pairs $1-14$ are for the assemblage margarite + plagioclase + quartz. Pairs $15-20$ are for the assemblage margarite + plagioclase + quartz $+k y a n i t e$. *From Orville (1972).

kyanite and $\mathrm{H}_{2} \mathrm{O}$ are considered equal to unity, and the equilibrium constant for the solids becomes:

$K_{(2)}=\frac{\alpha_{\mathrm{An}}}{\alpha_{\mathrm{Mg}}}=\frac{X_{\mathrm{An}} \gamma_{\mathrm{An}}}{X_{\mathrm{Mg}} \gamma_{\mathrm{Mg}}}$

Equilibrium data for reaction (2) are given in Table 5. For the case that produces the largest shift to the right in Fig. 6, $X_{\mathrm{An}}=0.92, \gamma_{\mathrm{An}}=1.0$ and $X_{\mathrm{Mg}}=\mathrm{Ca} /(\mathrm{Ca}+\mathrm{Na})=0.65 ; \gamma_{\mathrm{Mg}}$ is assumed equal to unity. A value for $K_{(2)}$ of 1.41 is derived, shifting the equilibrium $25-50^{\circ} \mathrm{C}$ to higher temperatures. For the case that produces the largest shift to the left, $X_{\mathrm{An}}=0.32, \quad \gamma_{\mathrm{An}}=1.276, \quad X_{\mathrm{Mg}}=0.65$ and $\gamma_{\mathrm{Mg}}=1.0$. For this case $K_{(2)}$ is equal to 0.63 . A shift of about $125^{\circ} \mathrm{C}$ to lower temperatures is indicated in Fig. 6. It should be noted that these are the extreme cases; that is, the remaining seventeen margarite-plagioclase pairs produce shifts of reaction (2) that fall between these limits, closer to the location of reaction (2) in the CASH system. These results are consistent with the study of Bucher-Nurminen et al. (1983), who found that $K_{\mathrm{D}}$ decreases with increasing temperature in margarite + plagioclase-bearing rocks from the Alps.

Zoisite-clinozoisite equilibria. Prunier and Hewitt
(1985) constructed a phase diagram for zoisite and clinozoisite with the aid of field and experimental data. Coexisting zoisite and clinozoisite pairs are plotted on their phase diagram in Fig. 4, and suggest temperatures of the order of $450-550^{\circ} \mathrm{C}$, with an average of $510 \pm 35^{\circ} \mathrm{C}$, where $35^{\circ} \mathrm{C}$ represents one standard deviation.

Amphibole-plagioclase equilibria. Spear (1980) presented an empirical geothermometer based on the $\mathrm{NaSi} \rightleftharpoons \mathrm{CaAl}$ exchanges in coexisting amphibole and plagioclase. Application of Spear's model to eleven amphibole-plagioclase pairs gives temperatures of $425-455^{\circ} \mathrm{C}$, with an average of $440 \pm 10^{\circ} \mathrm{C}$. The $\pm 10^{\circ} \mathrm{C}$ precision represents one standard deviation; it does not account for uncertainties inherent in the empirical calibration.

\section{Discussion of equilibria}

As described above, the portion of the CASH system of interest to this study has been well established experimentally and thus allows the best estimate of the $P-T$ path taken by the rocks at Seljeneset. The other equilibria that are discussed are not as well established. However, it is encouraging 
that they corroborate the conclusions based on equilibria in the CASH system.

A well-constrained retrograde path for the Seljeneset rocks has been derived by combining textural observations, equilibria in the CASH system, and temperatures and pressures derived from a number of other equilibria. The anorthosite was transformed into a kyanite + zoisite + quartz rock during the Caledonian orogeny at pressures greater than 8.2 kbar, and probably in excess of $15-17$ kbar. During retrograde metamorphism, kyanite porphyroblasts reacted with the zoisite + quartz matrix, via reaction (1), producing plagioclase-quartz reaction rims between $610^{\circ}$ and $800^{\circ} \mathrm{C}$. Subsequently, matrix and clots behaved as independent chemical systems.

There is no evidence that additional phases were produced in the matrix during continued cooling. Rather, a variety of continuous reactions proceeded, with different assemblages recording different temperatures, according to the specific blocking temperature of the phases involved. More specifically, zoisite-clinozoisite and amphibole-plagioclase pairs record average temperatures of $510 \pm 35^{\circ}$ and $440 \pm 10^{\circ} \mathrm{C}$, respectively.

In the clots, variable mineral composition, variable $K_{1}$, inferred reactions and pseudomorphic textures attest to a complicated history and indicate several generations of equilibria that are interpreted as a record of retrograde metamorphism where domains less than $1.0 \mathrm{~mm}$ in size did not equilibrate with their surroundings. The continuous reaction (2) proceeded from about $650^{\circ}$ to $450^{\circ} \mathrm{C}$, as margarite and quartz were produced at the expense of kyanite and plagioclase. Where $K_{\mathrm{D}}$ is approximately equal to unity this reaction resembles the discontinuous reaction (2) in the CASH system. Pressure is constrained to have been 4.3-8.2 kbar when the $P-T$ path crossed reaction (2). The rare three-phase assemblage, quartz + plagioclase $\left(A n_{x-22}\right)+$ kyanite, was preserved apparently due to the sodic composition of plagioclase, which produces a large displacement of reaction (2) to lower temperatures, significantly increasing the field of stability of the assemblage.

\section{Significance of the $P-T$ path}

Figure 7 shows the $P-T$ path derived in this study together with a number of previously published $P$ -

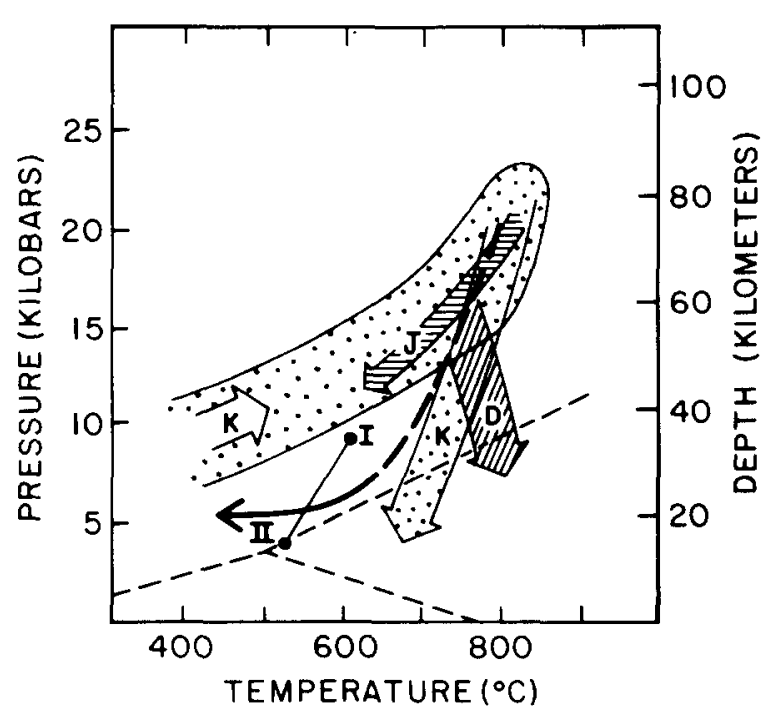

Fig. 7. P-T path derived in this study compared with previously published $P-T$ paths for the WGR, including $(K)$ the prograde trend of Krogh (1977), and the retrograde trends of $(J)$ Jamtveit (1984), (K) Krogh (1977) and (D) Dunn et al. (1984). Invariant points $I$ and II and the aluminum silicate phase diagram shown for reference.

$T$ paths, including the prograde trend of Krogh (1977), and the retrograde trends of Krogh (1977), Dunn et al. (1984) and Jamtveit (1984). Krogh's trends were derived from eclogites from many localities in the WGR, and therefore represent an "average" $P-T$ projectory for the WGR. The $P-T$ trends of both Dunn et al. and of Jamtveit were derived from studies from relatively restricted areas, both on the island of Gurskøy, aproximately $30 \mathrm{~km}$ north of Seljeneset. Thus, these results should represent $P-T$ paths for one structural unit, and presumably they should yield similar results because they involved localities less than $5 \mathrm{~km}$ apart. Jamtveit's trend was derived from ultramafic rocks at Gurskebotn, whereas that of Dunn et al. was derived from mafic rocks (eclogites) at Rødskar. Although the two studies yield similar conditions at $15 \mathrm{kbar}\left(700-800^{\circ} \mathrm{C}\right)$, the $P-T$ paths diverge at lower $P$, with Jamtveit's path crossing into the amphibolite facies, and that of Dunn et al. passing into the granulite facies. The reason ( $s$ ) for the disparity between the $P$ - $T$ paths is not clear. One possibility is that disequilibrium assemblages have been misinterpreted as equilibrium assemblages in one or both studies.

Medaris and Wang (1986) have recently pre- 
sented a theoretically-derived retrograde $P-T$ path for the WGR based on the tectonic model of Cuthbert et al. (1983). Boundary conditions employed by Medaris and Wang were eclogite-facies $P-T$ estimates, Devonian exposure of the WGR, and geochronologic constraints. The path derived by Medaris and Wang passes between IP's I and II, consistent with the results of the present study.

Although complicated textural relations were encountered in this study, it is clear that the retrograde $P-T$ path passed between IP's I and II (Figs. 5-7). As most of the WGR has been extensively retrogressed in the amphibolite facies, amphibolitefacies $P-T$ estimates are important for a complete characterization of the WGR during the Caledonian orogeny. In previous studies that have yielded retrograde $P-T$ information, data are available only at $T>650^{\circ} \mathrm{C}$. This study provides a well-defined constraint on the retrograde $P-T$ path that one element of rock passed through during the Caledonian orogeny.

\section{Acknowledgements}

Funding from the Department of Geology, University of Wisconsin, allowed the senior author to visit the Seljeneset locality and to conduct the microprobe investigation. W.L. Griffin is thanked for introducing the senior author to the project and for supplying several of the samples used in the study.

\section{References}

Albec. A.L. and Ray, L.. 1970. Correction methods for electron probe microanalysis of silicates, oxides, carbonates, phosphates, and sulfates. Anal. Chem., 42: 1408-1414.

Bence, A.E. and Albee. A.L.. 1968. Empirical correction factors for the electron microanalysis of silicates and oxides. J. Geol. 76: 382-408.

Bryhni, I.. 1966. Reconnaissance studies of gneisses, ultrabasites, eclogites and anorthosites in outer Nordfjord. western Norway. Nor. Geol. Unders., No. 241, 68 pp.

Bryhni. I., Krogh. E.J. and Griffin, W.L., 1977. Crustal derivation of Norwegian eclogites: a review. Neues Jahrb. Mincral. Abh., 130:49-68.

Bucher-Nurminen, K.. Frank, E. and Frey, M.. 1983. A model for the progressive regional metamorphism of margaritebearing rocks in the central Alps. Am. J. Sci.. 283-A: $370-395$

Chatterjee, N.D., Johannes, W. and Leistner, H., 1984. The system ( $\mathrm{aO}-\mathrm{Al}_{2} \mathrm{O}_{2}-\mathrm{SiO}_{2}-\mathrm{H}_{2} \mathrm{O}$ : new phase equilibria data. some calculated phase relations, and their petrological ap- plications. Contrib. Mineral. Petrol., 88: 1-13.

Cuthbert, S.J., Harvey, M.A. and Carswell, D.A.. 1983. A tectonic model for the metamorphic evolution of the Basal Gneiss Complex, western south Norway. J. Metamorph. Geol.. 1: 63-90.

Dollase. W.A., 1971. Refinement of the crystal structure of epidote, allanite and hancockite. Am. Mineral. 56: 447-464.

Dunn, S.R., Medaris, L.G. and Wang, H.F.. 1984. A thermaltectonic model for metamorphism of basic rocks in the Caledonides of wastern Norway. Geol. Soc. Am.. Abstr. Prog. 16: 496.

Eskola. P.. 1921. On the eclogites of Norway. Skr. Vidensk. Selsk. Christiana. Mat.-Nat. KI. 1, No. 8, pp. 1-118.

Goldsmith, J.R.. 1981. The join $\mathrm{CaAl}_{2} \mathrm{Si}_{2} \mathrm{O}_{\mathrm{x}}-\mathrm{H}_{2} \mathrm{O}$ (anorthitewater) at elevated pressures and temperatures. Am. Mineral. 66: $1183-1188$.

Griffin. W.L. and Brueckner, H.K.. 1980, Caledonian Sm-Nd ages and a crustal origin for Norwegian eclogites. Nature (London), 285: 319-321.

Griffin. W.L., Austrheim, H.. Bradstad. K.. Bryhni. I., Krill, A.G., Krogh, E.J., Mork, M.B.E., Qvale, H. and Torudbakken, B., 1985. High-pressure metamorphism in the Scandinavian Caledonides. In: D.J. Gee and B.A. Sturt (Editors). The Caledonide Orogen - Scandinavia and Related Areas. Wiley, London, pp. 783-801.

Holdaway. M.J.. 1971. Stability of andalusite and the aluminum silicate phase diagram. Am. J. Sci., 271: 97-131.

Jamiveit. B.. 1984. High-P metamorphism and deformation of the Gurskeboln garnet peridotite. Sunnmore. western Norway. Nor. Geot. Tidsskr.. 64: 97-110.

Jenkins, D.M., 1985. Upper pressure stability limits on synthetic margarite plus quartz. Contrib. Mineral. Petrol., 88 : $332-339$

Kerrick. D.M. and Jacobs, G.K., 1981. A modified Redlich$\mathrm{K}$ wong equation for $\mathrm{H}_{2} \mathrm{O}, \mathrm{CO}_{2}$ and $\mathrm{H}_{2} \mathrm{O}-\mathrm{CO}_{2}$ mixtures at elevated pressures and temperatures. Am. I. Sci., 281 : $735-767$.

Krogh. E.J.. 1977. Evidence of Precambrian continent-continent collision in western Norway. Nature (London), 267 : 17-19.

Lappin. M.A.. 1966. The field relationships of basic and ultrabasic masses in the Basal Gneiss Complex of Stadlandet and Almklovdalen. Nordfjord, southwestern Norway. Nor. Gcol. Tidsskr., 46: 439-496.

Lappin. M.A. and Smith, D.C.. 1978. Mantle-equilibrated orthopyroxene eclogite pods from the basal gneisses in the Selje district, western Norway. J. Petrol.. 19: 530-584.

Lappin, M.A., Pidgeon, R.T. and van Breemen. O.. 1979. Geochronology of basal gneisses and mangerite syenites of Stadlandet, west Norway. Nor. Geol. Tidsskr., 59: $161-181$.

Leake, B.E., 1978. Nomenclature of amphiboles. Mineral. Mag., 42: 533-563.

Lux. D.R.. 1985. K/Ar ages from the Basal Gneiss Region, Stadlandet area, western Norway. Nor. Geol. Tidsskr.. 65: 277-286

Medaris, L.G., 1984. A geothermobarometric investigation of garnet peridotites in the Western Gneiss Region of Norway. Contrib. Mineral. Petrol.. 87: 72-86. 
Medaris, L.G. and Wang, H.F., 1986. A thermal-tectonic model for high-pressure rocks in the Basal Gneiss Complex of western Norway. In: W.L. Griffin (Editor), Second International Eclogite Conference. Lithos, 19: 299-315 (special issue).

Newton, R.C. 1966. Kyanite-sillimanite equilibria at $750^{\circ} \mathrm{C}$. Science, 151: 1222-1225.

Nitsch. K.-H., Storre, B. and Töpfer, U., 1981. Experimentelle Bestimmung der Gleichgewichtsdaten der Reaktion 1 Margarit +1 Quartz $=1$ Anorthit +1 Andalusit/ Disthen + I H, O. Fortschr. Mineral., 59: 139-140.

Orville, P.M.. 1972. Plagioclase cation exchange equilibria with aqueous chloride solution: results at $700^{\circ} \mathrm{C}$ and 2000 bars in the presence of quartz. Am. J. Sci., 272: 234-272.

Perkins. D., Westrum. E.F. and Essene. E.J., 1980. The ther- modynamic properties and phase relations of some minerals in the system $\mathrm{CaO}-\mathrm{Al}_{2} \mathrm{O}_{3}-\mathrm{SiO}_{2}-\mathrm{H}_{2} \mathrm{O}$. Geochim. Cosmochim. Acta, 44: 61-84.

Prunier, A.R. and Hewitt, D.A., 1985. Experimental observtions on coexisting zoisite-clinozoisite. Am. Mineral., 70: 375-378.

Spear, F.S., 1980. $\mathrm{NaSi}=\mathrm{CaAl}$ exchange equilibrium between plagioclase and amphibole: an empirical model. Contrib. Mineral. Petrol., 72: 33-41.

Valley, J.W. and Essene, E.J., 1980. Calc-silicate reactions in Adirondack marbles: The role of fluids and solid solution. Geol. Soc. Am. Bull., 91: 114-117; 720-815.

Wall, V.J. and Essene, E.J., 1972. Subsolidus equilibria in $\mathrm{CaO}-\mathrm{Al}_{2} \mathrm{O}_{3}-\mathrm{SiO}_{2}-\mathrm{H}_{2} \mathrm{O}$. Geol. Soc. Am., Abstr. Progr.. 4: 700 . 